\title{
Photo-alignment control of topological defects in nematic liquid-crystal cells
}

\author{
Golub P. V. and Vasnetsov M. V. \\ Institute of Physics of the National Academy of Sciences of Ukraine, Prospect \\ Nauky 46, 03028 Kyiv, Ukraine, pvgolub@live.com
}

Received: 17.02 .2021

\begin{abstract}
We report the experiments aimed at controlling the position of linear topological defect (disclination) in a so-called $\theta$-cell filled with a nematic liquid crystal sandwiched between circularly rubbed polyimide (Kapton) layer and photoaligning PVCN material oriented unidirectionally. To satisfy surface-alignment conditions, the director within this cell experiences a twist. The topological defect appears in a plane where the twist angle of the director becomes indeterminate $\left( \pm 90^{\circ}\right)$. In an achiral liquid crystal, orientation of the disclination coincides with the alignment occurring on the unidirectionally oriented substrate. The idea of this work is to control the alignment direction on the substrate by a polarized ultraviolet light. Photo-induced director reorientation on the substrate changes the twist angle in the bulk and so varies the azimuthal angle of the disclination. We monitor reorientation of the disclination as a function of light-polarization angle and irradiation dose.
\end{abstract}

Keywords: liquid crystals, photo-alignment, topological defects, disclinations

UDC: $535.21+539.2$

\section{Introduction}

Application of photo-alignment to liquid crystals (LCs) is one of the hottest topics in the modern applied physics of LCs. It can result in widely ranging applications, some of which could become good alternatives to traditional surface-rubbing techniques, while the others could not be implemented with the latter technique [1-3]. In most cases, photosensitive aligning layers are irradiated with a polarized light before a cell is filled with a LC. However, photo-alignment of LCs is also frequently used after a cell is filled, i.e. in a freshly filled LC cell [4]. Moreover, some mechanisms of LC orientation are based on the polarization-sensitive absorbance of LC molecules, e.g. in a bulk-mediated photo-alignment technique [5-10].

The photo-alignment performed at a substrate of a LC cell dictates the boundary orientation of LC in a cell. Then the variation of its orientation on a substrate surface should also influence the LC director in the bulk $[4,11,12]$. This effect can be applied to control topological defects in the cell volume, which are created due to $\pm 90^{\circ}$ uncertainty in the angle of twist of the director occurring between the substrates.

In this work we suggest a technique for controlling linear topological defects formed in socalled $\theta$-cells. These cells are composed of two substrates, one of which is circularly rubbed. A (unidirectional) alignment of the director at the other substrate can be controlled due to irradiation of the cell by a linearly polarized light.

\section{Materials and experimental setup}

In our experiments, we used $\theta$-cells of LCs of a special design. A typical construction of the cell is shown in Fig. 1. The cell was composed of two substrates. One of them, a reference substrate, was covered with a polyimide (Kapton) layer, whereas a control substrate was covered with 
fluoro-polyvinyl-cinnamate (PVCN) film [13]. The polyimide film on the reference substrate was circularly rubbed, which provided strong circular alignment of the LC [4]. The gap between the substrates formed by calibrated spacers corresponded to the cell thickness $d=25 \mu \mathrm{m}$. The cell was filled with a nematic LC 5CB (4-Cyano-4'-pentylbiphenyl) in its isotropic phase (at the temperature $40^{\circ} \mathrm{C}$ ), using capillary forces. Unidirectional orientation of the nematic director at the substrate covered by PVCN can be controlled by linearly polarized light. To preset the alignment on the control substrate, it was irradiated with the polarized light from an ultraviolet diode laser (the wavelength of $405 \mathrm{~nm}$ ) before the cell was filled with the LC.

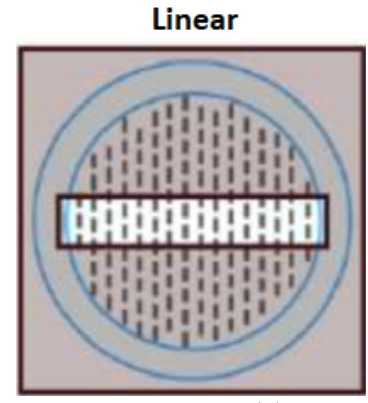

(a)

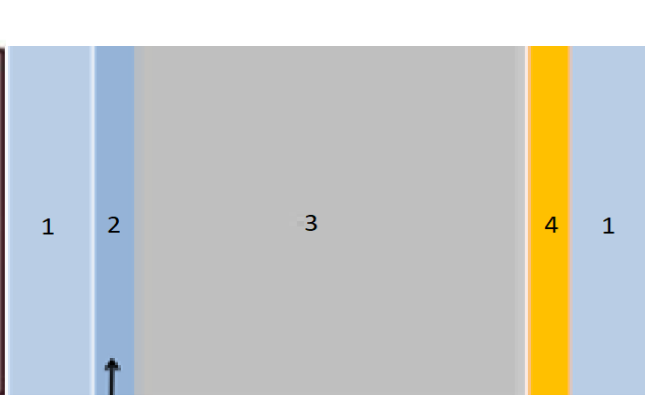

(b)

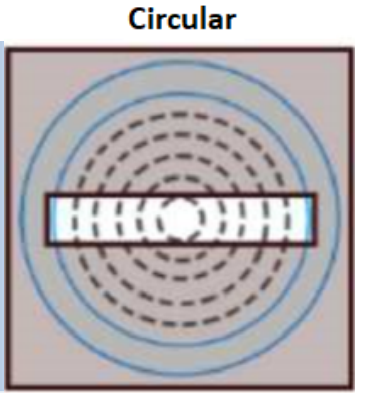

(c)

Fig. 1. Construction of our LC cell: (a) LC alignment on the control substrate; (b) sandwich of glass substrates (1), photosensitive PVCN (2), LC (3) and circularly rubbed polyimide layer (4); (c) LC alignment on the reference substrate.

The construction of the cell is schematically depicted in Fig. 2. The orientation of the LC director in the cell between the substrates is gradually twisted from unidirectional one (at the control substrate - see Fig. 2a) to the final state which satisfies the alignment determined by the circular rubbing of the reference substrate (see Fig. 2c). In a plane where the angle between the alignments provided on the control and reference substrates makes the twist $\pm 90^{\circ}$, a topological defect occurs, which has the shape of a disclination line [14]. It is known that the disclination line in the $\theta$-cells filled with achiral nematic liquid crystals is parallel to the unidirectional alignment [14] (see Fig. 2b).

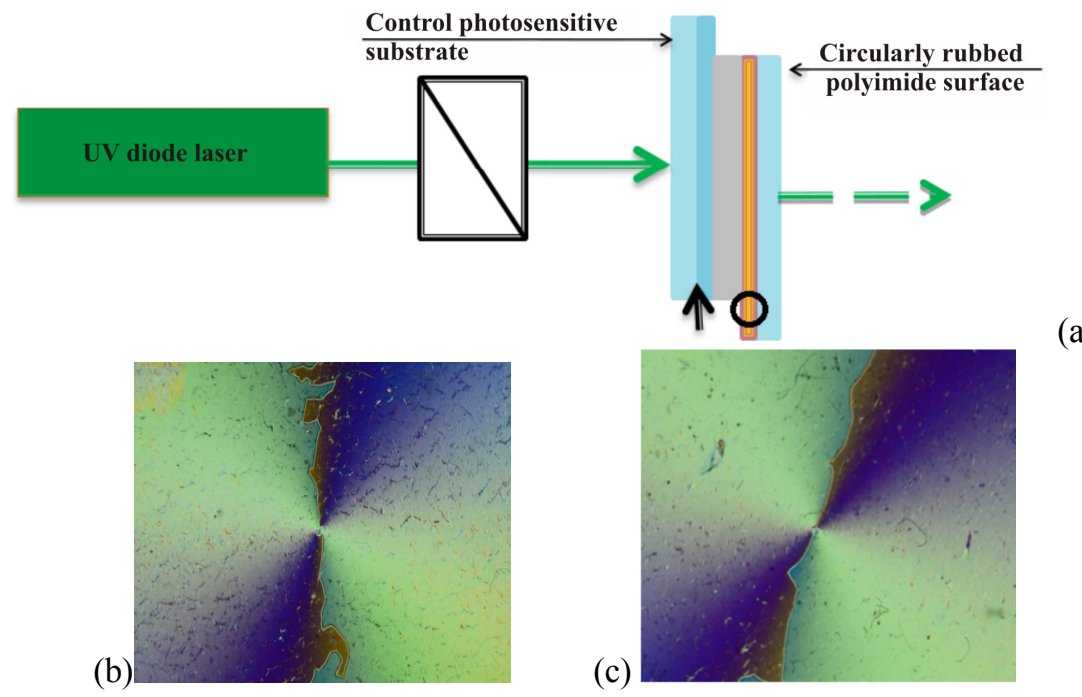

Fig. 2. (a) Sketch of our experiment, (b) $\theta$-cell before irradiation (the orientation angle $\varphi=0^{\circ}$ ), and (c) $\theta$-cell after irradiation (the reorientation angle $\varphi=15^{\circ}$ ). 
The cell prepared and filled as explained above was irradiated by the ultraviolet diode laser which emitted linearly polarized light. The time of irradiation varied from 10 to $150 \mathrm{~min}$ (i.e., $2.5 \mathrm{~h}$ ). The appropriate intensity was measured by a powermeter.

In most of our experiments, the LC cell faced the input ultraviolet beam by its control surface, i.e. the PVCN film was exposed at first (see Fig. 2a). After the exposure, the irradiated areas were examined between crossed polarizers, using a microscope Olympus BX53 equipped with a CCD camera connected to a computer. Note that reorientation of the disclination line was unambiguously detected, as seen from Fig. $2 \mathrm{~b}$ and Fig. 2c.

\section{Experimental results}

It is known that the light-induced azimuth angle $\varphi$ depends on the intensity $I$ of ultraviolet beam and the exposure time $t_{\text {exp }}$. The twist angle $\varphi$ increases with increasing intensity, with further saturation to a steady state determined by the total light dose [4].

When the cell is irradiated by the polarized light with the polarization plane producing some angle $\varphi_{0}$ with respect to the unidirectional pre-alignment at the control face, the angle of the disclination in the cell differs from the initial one (see Fig. 2c). It has been found that reorientation of the alignment on the control surface causes changes in the whole LC volume and the disclination line follows the azimuth $\varphi$, in accordance with orientation taking place on the control substrate. The experimental dependence of reorientation angle of the disclination on the irradiation dose is shown in Fig. 3.

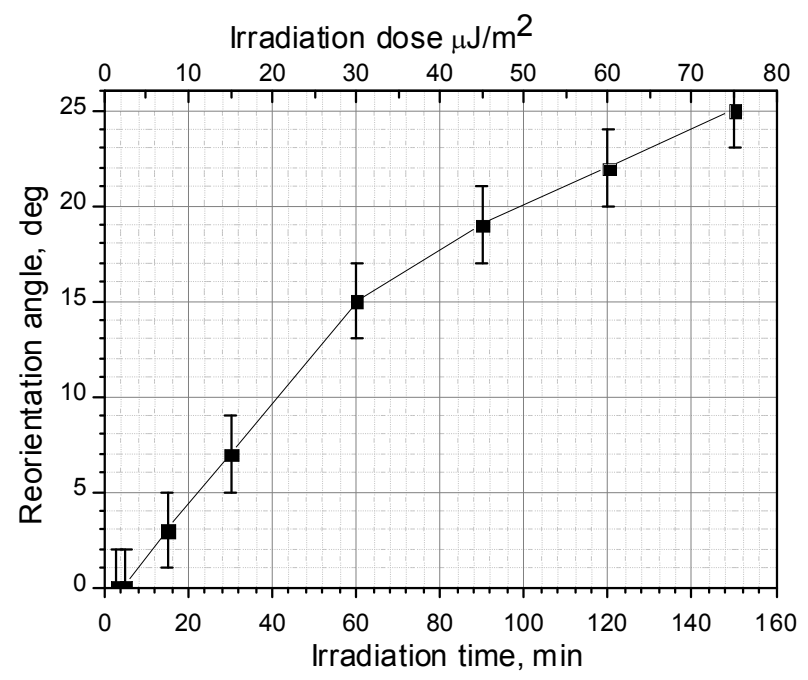

Fig. 3. Dependences of reorientation angle $\varphi$ of the disclination on the irradiation dose and time.

One can see from Fig. 3 that the characteristic time necessary for achieving the stationary state described by the angle $\varphi \approx 25^{\circ}$ is equal to $t_{\text {exp }} \approx 150 \mathrm{~min}$. This time characterizes a lightinduced development of a new 'easy axis' on the PVCN surface. According to Ref. [15], this time is associated with the time needed for settling equilibrium for the angular distribution of adsorbed LC molecules on the photosensitive surface during the irradiation process.

Hence, variations occurring in the boundary angular distribution eventually cause the changes in the director distribution in the overall LC volume. As a result, the topological defect changes its position according to orientation acquired on the photosensitive surface. In this way we are able to move the disclination azimuth in both angular directions.

Ukr. J. Phys. Opt. 2021, Volume 22 


\section{Conclusion}

We have demonstrated the possibilities for controlling the position of the topological defect in the LC bulk using the photo-alignment occurring on the border surface. It has been shown that the disclination direction in achiral LCs follows its orientation direction on the control substrate. Then the light-induced reorientation is possible. This technique can be used for precise control and deposition of particles trapped at the topological defect, as well as in irradiation dosimetry or in some other fields.

\section{Acknowledgement}

This study was performed within the Project "Photophysics of the processes of interaction of optical radiation with photorefractive solid-state and bio-organic media" by the National Academy of Sciences of Ukraine.

\section{References}

1. Yaroshchuk O and Reznikov Y, 2012. Photoalignment of liquid crystals: basics and current trends. J. Mater. Chem. 22: 286-300.

2. Guo Q, Srivastava A K, Chigrinov V G and Kwok H S, 2014. Polymerand azo-dye composite: a photo-alignment layer for liquid crystals. Liq. Cryst. 41: 1465-1472.

3. Hyo Kang, Yong-Seok Choi, Daeseung Kang and Jong-Chan Lee, 2015. Photoalignment behaviour on polystyrene films containing chalcone moieties. Liq. Cryst. 42: 189-197.

4. Sheremet N, Golub P, Kurioz Y, Trunov M and Reznikov Y, 2015. Light-induced LC director freezing on a chalcogenide surface. Liq. Cryst. 43: 249-255.

5. Voloshchenko D, Khyzhnyak A, Reznikov Y and Reshetnyak V, 1995. Control of an easyaxis on nematic-polymer interface by light action to nematic bulk. Japan. J. Appl. Phys. 34: 566-571.

6. Reznikov Y, Ostroverkhova O, Singer K, Kim Jae-Hoon, Kumar S, Lavrentovich O, Wang B and West John L, 2000. Photoalignment of liquid crystals by liquid crystals. Phys. Rev. Lett. 84: 1930-1933.

7. Ouskova E, Fedorenko D, Reznikov Y, Shiyanovskii S V, Su L, West J L, Kuksenok O V, Francescangeli $\mathrm{O}$ and Simoni F, 2001. Hidden photoalignment of liquid crystals in the isotropic phase. Phys. Rev. E. 63: 021701-021705.

8. Lee C-R, Fu T-L, Cheng K-T, Mo T-S and Fuh A Y-G, 2004. Surface-assisted photoalignment in dye-doped liquid crystal films, Phys. Rev. E. 69: 031704. doi:10.1103/PhysRevE.69.031704

9. Fedorenko D, Slyusarenko K, Ouskova E, Reshetnyak V, Ha KiRyong, Karapinar R and Reznikov Yu, 2008. Light-induced gliding of the easy orientation axis of a dye-doped nematic liquid crystal. Phys. Rev. E. 77: 061705.

10. Guo R, Reznikov Y, Slyusarenko K and Kumar S, 2008. Dynamics of molecular exchange between aligning adsorbed film of liquid crystal and the bulk. Appl. Phys. Lett. 92: 121911.

11. Sheremet N, Kurioz Y, Senenko A, Trunov M and Reznikov Yu, 2015. Photoalignment in the isotropic phase of liquid crystal on chalcogenide glass film. Liq. Cryst. 42: 81-86. doi:10.1080/02678292.2014.965231

12. Andrienko D, Francescangeli O, Ouscova E, Simoni F, Slussarenko S and Reznikov Yu, 1998. Laser beam modulation freezing on a liquid crystal surface. Mol. Cryst. Liq. Cryst. 320: 69-76. 
13. Buluy O, Iljin A, Ouskova E, Reznikov Y, Blanc C, Nobili M and Antonova K, 2006. Anchoring and gliding of easy axis of $5 \mathrm{CB}$ on photoaligning PVCN-F surface. J. Soc. Inform. Disp. 14: 603-610.

14. Vasnetsov M V, Pas'ko V A and Kasyanyuk D S, 2011. Observation of polarization conflict caused by geometrical phase in a twisted nematic liquid crystal cell. Opt. Lett. 36: 2134-2136.

15. Sheremet N, Kurioz Y, Klebanov M, Lyubin V, Slyusarenko K and Reznikov Yu, 2012. Photoinducedanchoring on a chalcogenide surface. Phys. Rev. E. 85: 051703.

16. Andrienko D, Dyadyusha A, Iljin A, Kurioz Yu and Reznikov Yu, 1998. Measurement of azimuthal anchoring energy of nematic liquid crystal on photoaligning polymer surface. Mol. Cryst. Liq. Crys. Sci. Tech. Sect. A. 321: 271-281.

Golub P. V. and Vasnetsov M. V. 2021. Photo-alignment control of topological defects in nematic liquid-crystal cells. Ukr.J.Phys.Opt. 22: 87 - 91. doi: 10.3116/16091833/22/2/87/2021

Анотація. Ми повідомлясмо про експерименти, спрямовані на керування рухом лінійного топологічного дефекту (дисклинації) у т. зв. $\theta$-коміриі, заповненій нематичним рідким кристалом, який затиснуто між цииркулярно натертим поліімідним (каптонівським) шаром та односпрямовано орієнтованим фотовирівнюючим матеріалом РVСN. Щоб задовольнити умови вирівнювання на поверхні, директор у иій коміриі зазнає скручування. Топологічний дефект з'являється в площині, де кут скручування директора стає невизначеним $\left( \pm 90^{\circ}\right)$. В ахіральному рідкому кристалі орієнтація дисклинації збігається 3 напрямком вирівнювання, щуо має місие на односпрямовано орієнтованій підкладиі. Ідея иієї роботи полягає в керуванні напрямком вирівнювання на підкладиі за допомогою поляризованого ультрафіолетового світла. Фотоіндукована переорієнтація директора на підкладиі змінює кут скручування в об'ємі рідкого кристала, а тому й азимутальний кут дисклинації. Ми також відстежили переорієнтацію дисклинації як функцію кута поляризаиії світла та дози опромінення. 